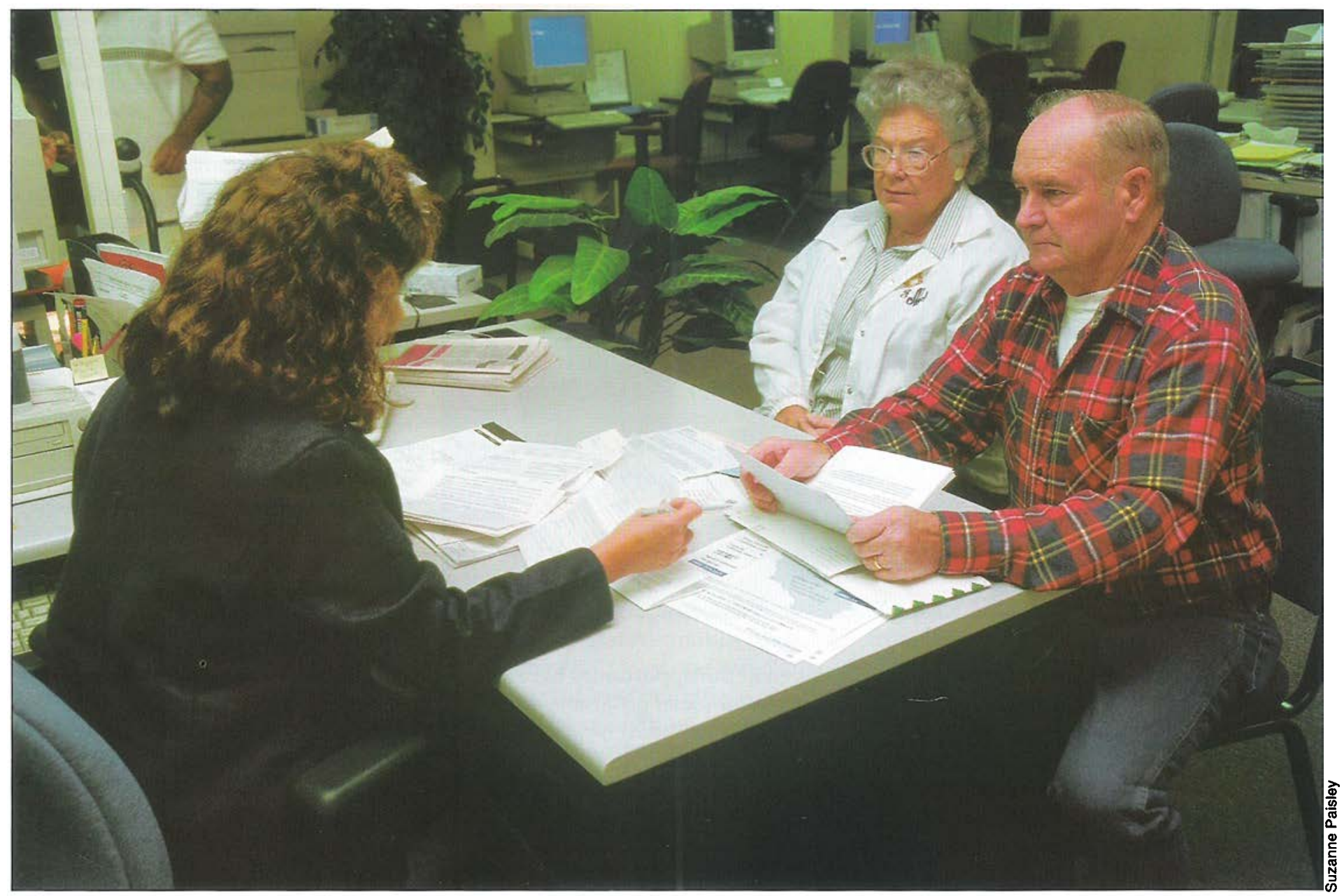

\title{
Welfare reform shines a light on work-force development challenges
}

Federal welfare reform, which requires most welfare recipients to work, is reshaping social services. At the Butte Community Employment Center, which opened in 1998 , resource specialist Anna Uribe serves employers and job seekers without regard to eligibility for any program.

David Campbell

In August 1996, Congress passed sweeping reforms to the nation's welfare system, requiring most recipients to work and placing a 5year Ilmit on benefits. The California Communities Program at UC Davis has been studying the progress of welfare reform in six California counties, and comparing the state's experience to national trends. Through more than 200 interviews and an extensive literature review, we have found that welfare reform is succeeding in reducing caseloads and reinventing local social-service bureaucracies. But these changes must be jolned with long-term job creation and work-force development strategies if they are to truly reduce poverty. California's welfare reform policies and experiences highlight the particular challenges facing rural counties, which generally have fewer staff resources, a less-developed infrastructure of nonprofit service organizations, and lower expectations about their ability to implement major reforms.
$\mathrm{T}$ has been more than 3 years since Longress passed the Personal Responsibility and Work Opportunity Reconciliation Act of 1996, calling for sweeping changes of the nation's welfare programs. Welfare reform ended the entitlement to welfare cash-aid, replacing it with a system of time-limited support that requires all nonexempt participants to work or participate in work-related activities. Aid recipients face a 5-year lifetime limit on benefits, and are sanctioned if they fail to comply with work participation requirements. This new focus on job readiness 
on the run, designing required program elements before complementary elements have been fully thought out, and granting front-line, social-service agency staff greater discretion before they are fully retrained.

The tasks counties face are daunting. These include reinventing the welfare bureaucracy and communityservice delivery network around the new emphasis on employment; expanding support services such as child care, transportation and life skills; and developing new data-management systems that identify client job readiness and track work-related activities. All this activity is taking place under the pressure of tight federal timelines for meeting work participation quotas, and ever-evolving accountability requirements.

Early outcomes in the state are mixed. As of the 1998 to 1999 federal fiscal year, California had met the work participation rates required under federal law, avoiding (at least for now) the possibility of a hefty fiscal sanction. Welfare caseloads declined 30\% between August 1996 and March 1999 , a much smaller reduction than in most states (California is tied for $42 \mathrm{nd}$ among the 50 states). While many recipients are getting jobs, a good deal of the decline can be attributed to a low compliance rate. A CalWORKs evaluation by RAND, the Santa Monicabased think tank, found that half or more of recipients simply fail to show up for scheduled activities, often resulting in sanctions that take away the adult portion of their family welfare grant (RAND 1999). California is one of a handful of states that chose not to sanction the child portion of welfare grants. Some observers believe this encourages noncompliance, since recipients who are sanctioned continue to receive cash-aid for their children, do not have to participate in work activities and see their 5-year lifetime clock stop.

California counties initially feared the effects of welfare reform on county budgets, especially the prospect of increased General Assistance obligations, the final safety net for people not covered by other welfare programs. To date, however, welfare department budgets have actually swelled dramatically. The reason is that the county share of the state block grant is based on 1994 caseload levels, even though rolls have since declined dramatically. Per-client budget allocations rose $25 \%$ from fiscal year 1998 to 1999 alone. In Kern County, the human services department budget increased $51 \%$ due to increases in welfare reform spending (with no new county funds involved), while spending for cash-aid decreased $\$ 50$ million due to reduced rolls. In fact, welfare departments are finding it hard to spend their entire block-grant allocations. The California Budget Project reports that in the current fiscal year counties (on average) are on pace to spend only half of their state allocations.

An issue of particular concern in California is the effect welfare reform has had on children in mixedimmigration-status families (those in which there is at least one noncitizen parent and at least one citizen child). A recent Urban Institute report found that the complex and sometimes competing goals of immigration and welfare policies often result in the denial of benefits to many eligible children (Fix and Zimmerman 1999). The authors note that $27 \%$ of all California children live in mixed-status families, compared with an average of $9 \%$ across the United States. Among all California low-income families with children, nearly one in three are mixed status.

\section{The experience of rural counties}

Rural counties face particular challenges in meeting the requirements of welfare reform (Garkovich and Irby 1998; Martin 1999). These include weaker governance capacity, higher rates of poverty, large numbers of seasonal jobs, and a decline in resourcebased industries due to economic restructuring. Our research indicates that rural counties face three major governance challenges: (1) fewer staff resources to manage systems change of the magnitude required by welfare reform; (2) a less vital set of large and capable nonprofit service-delivery and planning organizations to draw on for support; and (3) a perception that they lack control over their own political

\section{Until now, a remarkably buoyant civic spirit has marked welfare-reform implementation.}

and economic destinies, which can translate into greater hesitancy to launch major reform initiatives than more "sophisticated" urban counties.

Caseloads have declined rapidly in all California counties, but urban and rural distinctions are evident. In our six-county sample, the four "rural" and "rural/city" Central Valley counties (Butte, Kern, Sacramento and Tulare) lag behind the statewide average, and the two coastal "urban/suburban" counties (San Diego and Ventura) exceed it (fig. 1). A statewide comparison by the California Budget Project reveals that the 37 rural and rural/city counties lagged $5 \%$ behind

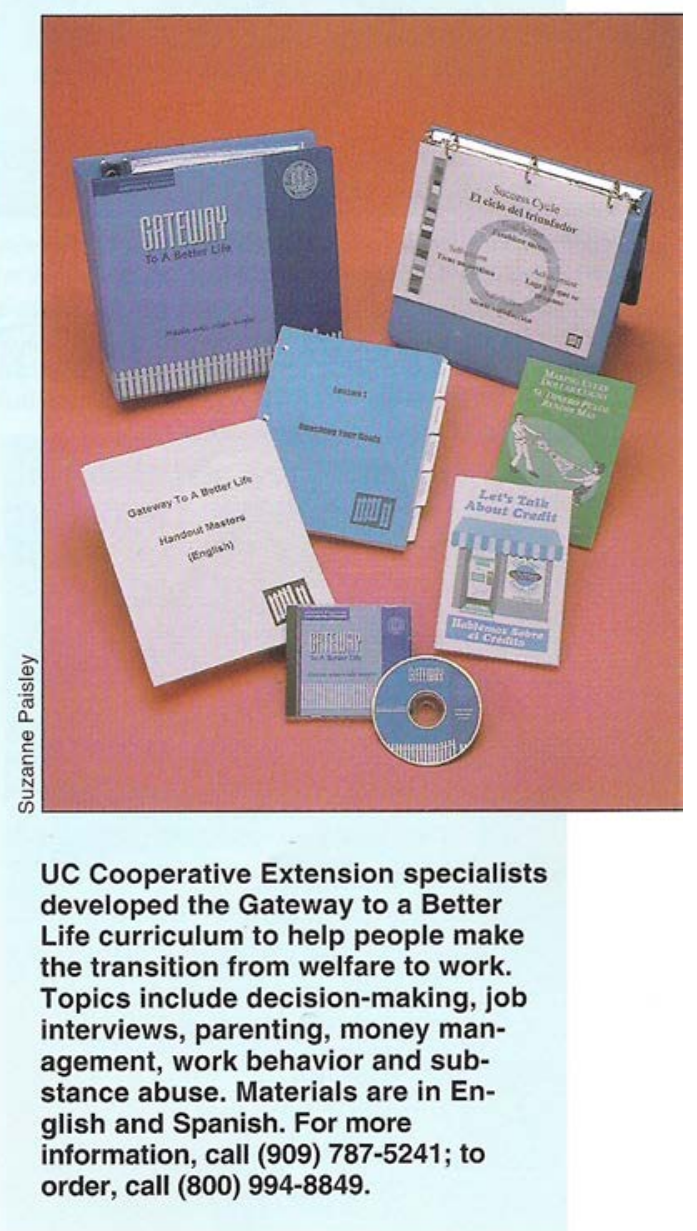




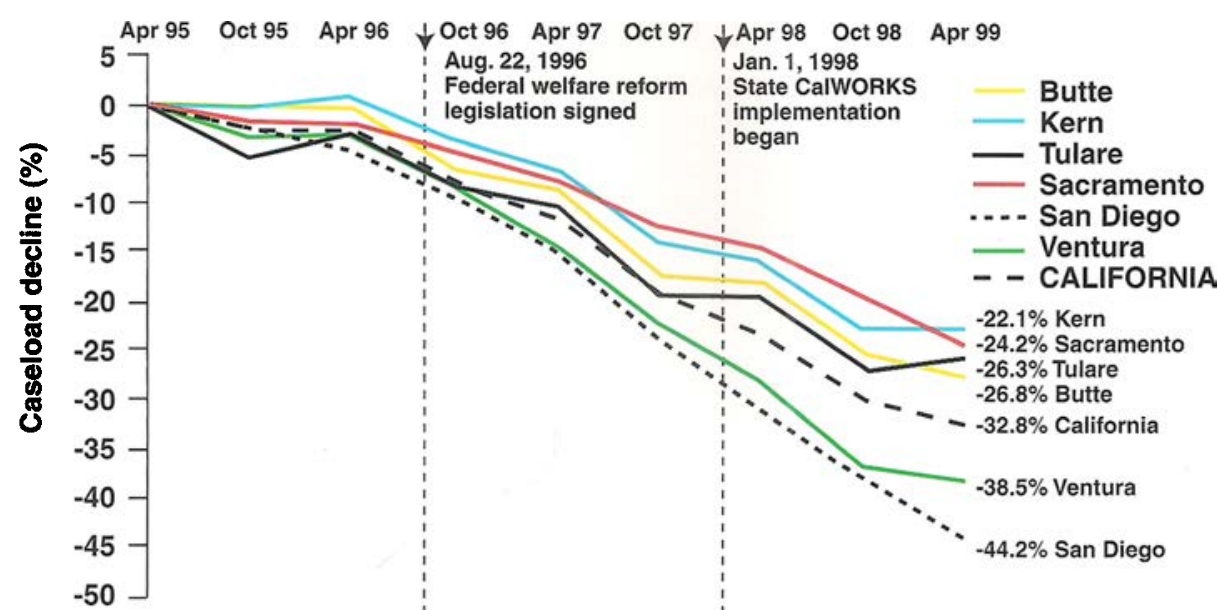

Fig. 1. Caseload decline comparisons in selected California countles, Aprll 1995-April 1999. Source: Californla Department of Soclal Services, TANF Cashgrant cases.

the state average between 1995 and 1998, while urban/suburban counties exceed the average by $1 \%$. The only national study of its type found that rural county caseloads are declining on pace with other areas (Rural Policy Research Institute 1999), but without the gains in labor-force participation rates or the decline in the working-age poverty rate experienced in urban areas.

As welfare rolls shrink and the CalWORKs population comes to include a higher percentage of "hard-toserve" clients, the rate of decline in caseloads is slowing in all counties. As this happens, the gap between caseload reductions in the rural and urban counties has begun to increase. Between October 1998 and April 1999, for example, urban/suburban counties experienced an average caseload decline of $5 \%$, while rural counties slowed dramatically to $1 \%$. Among our sample counties, the gap is particularly evident, with San Diego's caseload dropping $10 \%$ in the 6-month period, and Kern's caseload essentially remaining level.

Caseload reduction by itself is not necessarily a good indicator either of county program performance, or of how well communities are meeting goals related to family self-sufficiency and reduction of poverty. A 1998 California Legislative Analysts Office report noted that improvements in client "work readiness" would be a better measure of program performance, but no such data currently exist. Short of that, it is difficult to sort out the respective roles of county economic health, pre-existing work readiness of clients, and program performance in achieving caseload reduction.

Another current unknown is whether rural counties will in fact face fiscal penalties for failing to meet work-participation quotas. It was relatively easy for lawmakers to write these provisions into federal and state law, but it will be much more difficult to stick to them in the face of what is sure to be persistent criticism of the unfairness of penalizing economically distressed counties and regions.

California-specific data on what is happening to those who leave welfare is not yet available, in large part due to the difficulty all counties are having in creating new client tracking systems. Welfare officials we interviewed paint a picture not unlike the results of a national "leavers" study conducted by researchers from the Urban Institute (Loprest 1999). That report found that half or more of those leaving welfare are finding employment, but typically in low-wage, no-benefit jobs that leave them struggling to make ends meet. Average wages are in the $\$ 6.50$ per-hour range, far below the $\$ 8.36$ per-hour wage that RAND calculates is necessary for a family of three in California to become ineligible for cash aid (RAND 1999), and much less than the $\$ 10$ - to $\$ 12$-per-hour range which many consider the minimum for a living wage. Over one-third of those surveyed by the Urban Institute reported serious problems in providing their families with food, and $40 \%$ indicated problems paying rent.

To our knowledge, no researchers are currently tracking patterns of migration in relation to welfare reform. Hypothetically, welfare reform could either cause migration of rural welfare-to-work participants to cities in search of better employment opportunities, or migration of those sanctioned in cities to rural areas in search of more affordable housing. Anecdotal evidence from our interviews suggests that out-migration from California's rural areas is occurring, often to locations outside the state. For example, we have heard repeatedly that many Hmong refugees living in rural parts of the Central Valley have moved to the Upper Midwest or North Carolina. In Tulare County, where unemployment is in the double digits, both the County Office of Education and the Salvation Army run "train and transport" programs that relocate recipients to out-of-state job markets. The smallscale Salvation Army program targets urban areas with low unemployment rates, such as Las Vegas and Salt Lake City. The Tulare County MOVE (More Opportunity for Viable Employment) program supported the relocation of 130 families during the 9-month period ending in June 1999, many to meatpacking jobs in the Midwest. Other evidence of out-migration comes from Butte County officials, who point to a marked decline in public-school enrollments in the county as evidence. They caution, however, that recent business closings may have as much to do with this as welfare reform. While not in themselves conclusive, these examples suggest that the topic of welfare reformrelated migration is ripe for more focused empirical research to ascertain actual patterns and their significance.

\section{Workers and jobs}

Until now, a remarkably buoyant civic spirit has marked welfare-reform 
implementation. In both rural and urban areas, community leaders report an upsurge in civic conversation, and a multiplicity of new partnerships. These are fueled by a widely shared desire to seize the opportunity to "fix a broken system," and reinvent the work of welfare bureaucracies in terms that are more satisfying to caseworkers, clients and taxpayers. These partnerships also benefit from a rare convergence of increased county policy discretion at the same time that program resources are expanding. As an attempt to spur policy innovation in an area long known for recalcitrance and public divisiveness, welfare reform has clearly succeeded. But the success is bounded within limits set by economic circumstances and by the capacity of local service delivery systems to puzzle their way through issues of turf, jargon and control.

Two future scenarios are possible. In the first, and less desirable, the emphasis would continue to be solely on "work first" and on reducing caseloads, with little concern for longterm work-force development and job-creation strategies. Most of the "success" stories under welfare reform will graduate from cash-aid only to join the ranks of the working poor. In addition, the current program could create troubling inequities, since CalWORKs participants are eligible for subsidized child care, job training, community-service employment and case management, while the rest of the working poor are not.

Even more troubling is what could happen to the individuals who do not succeed under the "work first" approach. These include many individuals with disabilities, substance abuse and mental health issues, and victims of domestic violence. The good news is that welfare reform is providing the occasion for gathering clearer data on the extent of these problems among local populations. The bad news is that adequate treatment programs are often unavailable. Even where they are available, many of those most in need of treatment programs are being sanctioned for failing to participate in CalWORKs, and thus losing their eligibility for funded services. Over time, it is possible that the ranks of these "hopeless" individuals will grow in local areas, placing greater burdens on the community - particularly nongovernmental - safety net.

For rural areas, a narrow focus on caseload reduction would be particularly hazardous.

Over the past two decades the trend has been toward an increasingly bifurcated economic reality in which urban areas with strong industrial clusters prosper while rural areas suffer by comparison. Our interviews suggest that rural leaders increasingly see their communities as sites for employers whose need for lowwage, low-skilled workers matches a local work-force that is poorly trained, and often lacking English language and basic math skills. For example, one county economic development

planner told us they make a special effort to identify firms like warehouse distributors that are able to accommodate laborers without English or math skills. However necessary such actions may be in the short-run, they do not constitute an adequate long-range strategy.

A second, more hopeful scenario can also be envisioned. In this scenario local leaders adopt a long-haul perspective that emphasizes upgrading the local work-force, cooperating on regional economic development, and improving indicators of child and family well-being, such as the reduction of poverty. The Workforce Investment Act of 1998, less heralded than welfare reform but of equal long-term importance, provides a framework for more efficient and integrated delivery of job training services for all local residents, not just welfare recipients. Many counties are capitalizing on welfare re-

\begin{abstract}
Above, Soll analysis is one of many skills Mai Lee is learning at Butte County's job-training farm. Below, At the Northern California Food Service and Baking School, Kandy Rodriguez is being trained in all aspects of running a restaurant and full-service bakery.
\end{abstract}

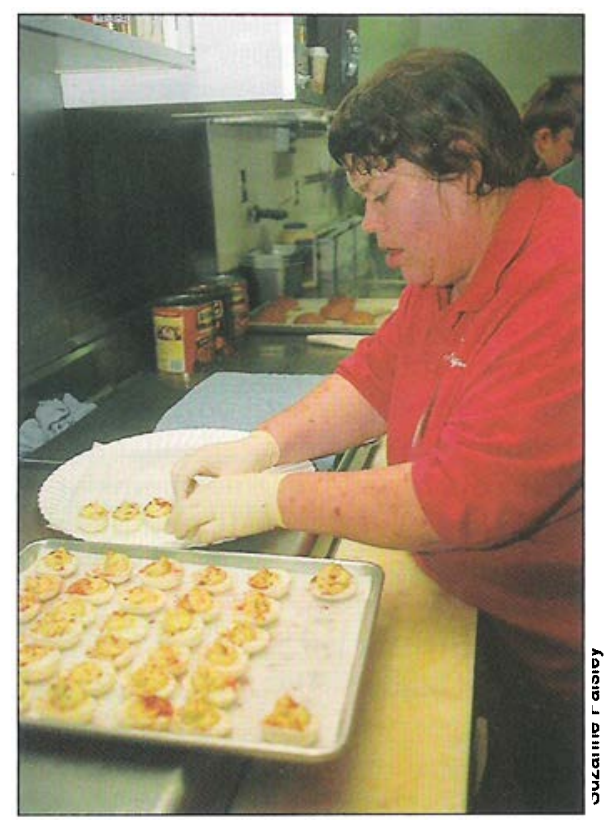




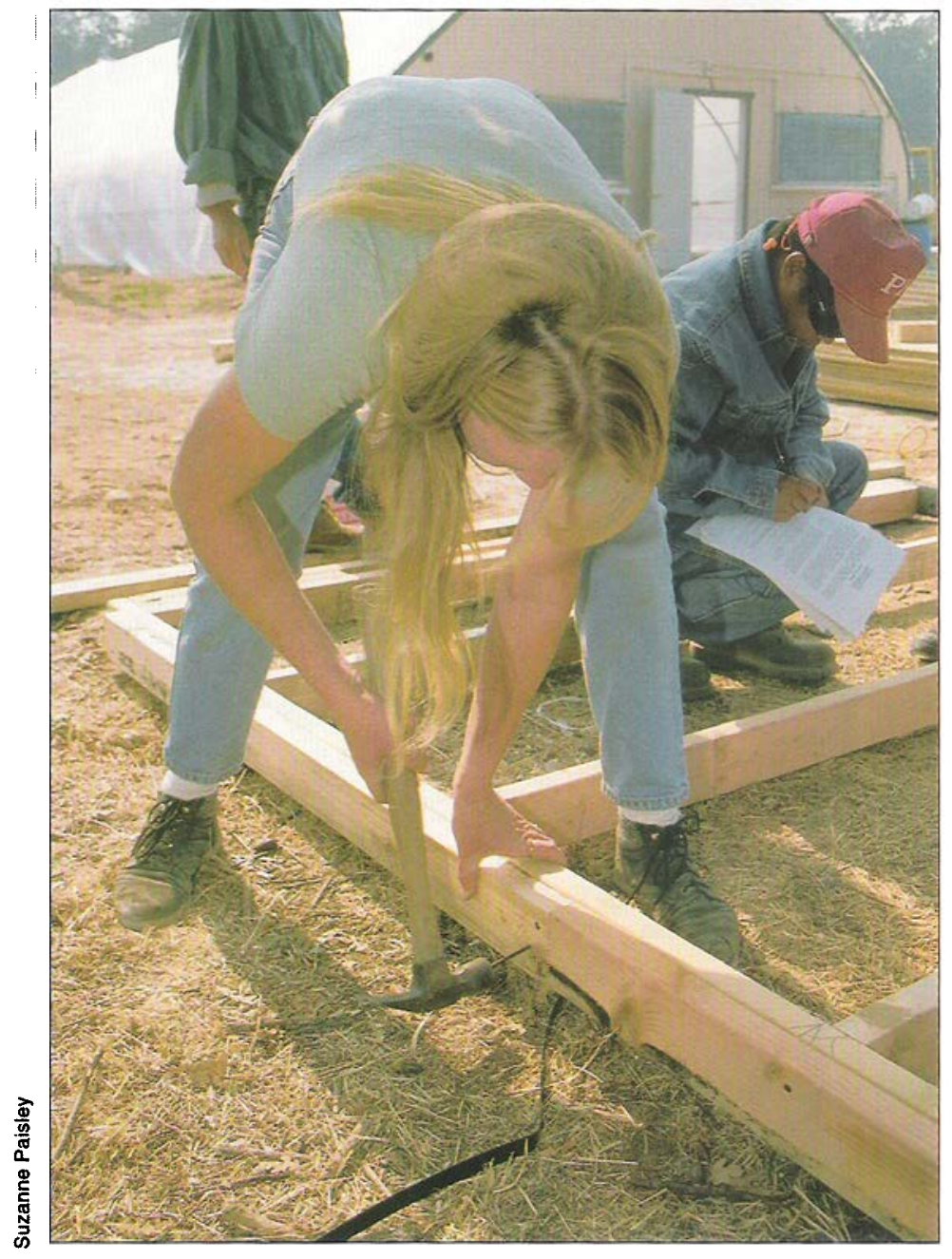

Butte County's On the Job Training program assures Kathy Dabbs and all participants a job after they complete the training; employers pay half of the wages during the training period.

form as an opportunity to start building a more integrated workforce development infrastructure. For example, Butte County has built a one-stop Community Employment Center in Chico, which provides services to all county residents regardless of whether they are receiving welfare.

Better-integrated work-force development efforts will only succeed if local organizations can meaningfully collaborate, muting claims of turf and ego and focusing on the particular needs of the local labor force. One test will be the type of claims local actors make on state and federal officials. Historically, particular organizations seek deals that enhance their own standing without reference to broader community needs. More helpful would be to witness a unified set of local stakeholders who can petition higher levels of government for the specific changes in funding mechanisms and other regulations they need to advance cooperative goals.

A continuing challenge over the coming decades will be to initiate economic development strategies that are suited to rural regions and small town settings. Rural areas cannot use Silicon Valley as the model, nor should they be content as sites for telemarketing centers and warehouses. Models of sustainable economic development that take advantage of the resource base to create value-added approaches must be developed.

The question of how local communities can provide living-wage jobs, or some combination of low-wage jobs and subsidized public support, looms large for the future. Rural communities have serious disadvantages on the wage side, which are only partially offset by advantages in terms of a lower cost of living. Interestingly, while welfare reform has proved a financial windfall to county welfare departments, it has not, as a rule, generated an increase in county government employees. Many counties have continued downsizing, preferring to outsource new hiring to private or nonprofit contractors so that they are not stuck with employees if future revenues decline. Since government jobs are one of the few stable sources of middle-class jobs in many rural communities, this trend appears to exacer- bate the labor market challenges already present.

\section{Future in focus: Opportunities and challenges}

Welfare reform and related aspects of policy devolution represent a significant opportunity for counties to advance beyond the weak-sister role they have normally played within American federalism. Currently, counties have increased both discretion and funding, making it possible to design and deliver programs that take unique features of local labor markets and the local work-force into account. For rural counties that continually struggle to implement preset programs more attuned to urban needs, this represents a significant opportunity. But the work-force development and job-creation challenges in rural areas are substantial. To succeed in the coming decades, they must build upon the popularity of the new "work first" emphasis in order to create community support for longterm public investments in education, training and job creation.

D. Campbell is Director, California Communities Program, Department of Human and Community Development, UC Davis.

\section{References}

Fix M, Zimmerman W. 1999. All under one roof: Mixed status families in an era of reform. Washington, DC: The Urban Institute. $21 \mathrm{p}$.

Garkovich L, Irby J. 1998. Where the rubber meets the road: New governance issues in America's rural communities. Southern Rural Development Center: The Rural Community Consortium, Mississippi State University. $8 \mathrm{p}$.

Loprest P. 1999. Families who left welfare: Who are they and how are they doing? Washington, DC: The Urban Institute. $27 \mathrm{p}$.

Martin P. 1999. Welfare reform in rural California: Issues and challenges. California Community Topics, No 5. UC Davis: California Communities Program. $4 \mathrm{p}$.

Nathan RP, Gais TL. 1999. A surprising first look: Implementing the Personal Responsibility and Work Opportunity Act of 1996. American Society for Public Administration: PA Times 22(6): 1-2.

RAND Statewide CalWORKs Evaluation. 1999. Welfare reform in California: State and county implementation of CalWORKs in the First Year. Santa Monica: RAND. $87 \mathrm{p}$.

Rural Policy Research Institute. 1999. Rural America and welfare reform: An overview assessment. Rural Welfare Reform Panel, University of Missouri. $35 \mathrm{p}$. 